\title{
Molecular typing of Neisseria gonorrhoeae by restriction fragment length polymorphisms
}

\author{
C L Poh, H P Khng, C K Lim, G K Loh
}

\begin{abstract}
Objective-To characterise Neisseria gonorrhoeae isolates by restriction fragment length polymorphisms (RFLPs) in ribosomal RNA genes.

Design-Generation of RFLP patterns by HincII restriction of rRNA genes followed by hybridisation with a nonradioactive labelled broad spectrum 16 $+23 S$ rRNA gene probe. This typing method was developed and compared with MAb based serotyping.

Specimens-Forty three randomly collected isolates from Bangkok (27 isolates) and Singapore (16 isolates) were studied.

Results-The RFLP patterns generated were reproducible and highly discriminatory between strains. Analysis of RFLPs produced by HincII restriction of $r R N A$ genes established 9 patterns amongst the 43 isolates examined. Strains present within a common serovar could be further subdivided by RFLP typing. Identical RFLP patterns were found in some strains that belonged to various serovars.

Conclusion-RFLP typing based on heterogeneities of rRNA gene restriction patterns could be advantageously used to complement monoclonal antibody based serotyping for further subdivision of serovars. Higher sensitivity of this combined approach would enable better differentiation of strains in epidemiological studies.
\end{abstract}

\section{Introduction}

Auxotyping and serovar determination have been accepted as the two major phenotypic systems for typing of Neisseria gonorrhoeae. Currently, the most widely employed method to differentiate $N$ gonorrhoeae isolates is one based on a combination of both methods, known as the auxotype-serovar (A/S) classification system. ${ }^{1}$ However, it has several limitations. Large numbers of isolates in Asia are either Prototrophic or of $\mathrm{Pro}^{-}$auxotype ${ }^{2}$. These isolates may in fact be very different strains despite sharing common auxotypes. Similarly, strains belonging to a particular serovar may not be identical as suggested by comparisons of other phenotypic characteristics such as antimicrobial susceptibility patterns, plasmid profiles and auxotypes. Other problems include the occurrence of non-typable strains, the need to develop new mono- clonals in anticipation of possible genetic drift in Protein I (PI), the continual production of monoclonals, batch to batch variations of monoclonals and the technical reproducibility of coagglutination reactions especially when using monoclonal antibodies such as $2 \mathrm{D} 6$, $2 \mathrm{G} 2$ and $6 \mathrm{D} 9^{3}$.

Molecular typing methods such as restriction endonuclease analysis (REA) of genomic DNA has been shown to be a sensitive technique for differentiation of $N$ gonorrhoeae serovars. ${ }^{45}$ However, owing to the complexity of DNA bands generated in either agarose or polyacrylamide gels, meaningful interpretations of DNA fingerprints are best made with quantitative comparisons of dendograms generated.

Specific DNA probes such as ribosomal ribonucleic acid (rRNA) based probes have been found to generate fewer bands in gels, making both interpretations and comparisons much easier. This approach has been found to provide excellent discrimination and reproducibility in the epidemiological typing of diverse groups of bacteria, for example, in the differentiation of Legionella pneumophila serogroup $1^{6}$, coagulase-negative staphylococci ${ }^{7}$, Helicobacter pylori $^{8}$ and meningococci $i^{9}$.

The aim of this study was to investigate the application of rRNA gene probe for the detection of restriction fragment length polymorphisms (RFLPs) in $N$ gonorrhoeae strains and to compare the rRNA gene patterns with serological characterisation.

\section{Materials and methods}

Gonococcal strains

A group of 27 random isolates collected in 1984 from Bangkok which had been serotyped with MAbs was kindly provided by SM Bygdeman. The remaining 16 strains used in this study were randomly isolated over 6 months in 1984 from male patients with urethritis from the Middle Road Hospital, Singapore. Serological characteristics of this latter set of strains have been described previously. ${ }^{5}$

\section{Preparation of DNA}

Genomic DNA was prepared using the in situ extraction method as described previously. ${ }^{5}$

Restriction enzyme digestion and electrophoresis Restriction endonucleases EcoRI, CfoI, ClaI and HincII were purchased from Bethesda Research Laboratories, Inc, Gaithersburg, Md, USA. DNA entrapped in agarose pellets was digested with restriction enzymes using
Address correspondence to: Dr C L Poh

Accepted for publication 28 November 1991 
buffers and reaction conditions as described previously. ${ }^{5}$ The digested DNA was electrophoresed at $25 \mathrm{~V}$ for $16 \mathrm{~h}$ in horizontal $0.8 \%$ (wt/vol) agarose (type II medium electroendomosis grade, Sigma, USA) gel in a TAE buffer system (0.04 M Tris, 0.04 M acetic acid, 0.002 M EDTA [pH 8.0]). After electrophoresis, the gel was stained with ethidium bromide, examined by UV transillumination and photographed. Southern blotting of DNA fragments to a nylon membrane (Hybond-N, RNN 303 N, Amersham) was performed in a vacuum pump unit (Vacugen; PharmaciaLKB) and the membranes were baked for $2 \mathrm{~h}$ at $80^{\circ} \mathrm{C}$.

\section{Preparation of non-radioactive labelled $r R N A$ probe}

The rRNA gene probe derived from plasmid pHF $1 \cdot 1$, which encodes the $16 \mathrm{~S}$ and $23 \mathrm{~S}$ rRNA genes of Pseudomonas aeruginosa was a gift from $\mathrm{K} \mathrm{H}$ Schleifer. ${ }^{10}$ The plasmid was digested with BstEII (New England Biolab, USA). The digested DNA fragments were separated by gel electrophoresis on $0.8 \%$ agarose gels. The $2.2 \mathrm{~kb}$ fragment containing the rRNA genes were isolated from agarose and labelled with horseradish peroxidase (ECL Gene detection system RPN 2101, Amersham) following the manufacturer's instructions. Briefly, the DNA at a final concentration of 10 $20 \mathrm{ng} / \mu \mathrm{l}$ was heated at $55^{\circ} \mathrm{C}$ for $10 \mathrm{~min}$, then cooled on ice for $5 \mathrm{~min}$. An equivalent volume of labelling reagent (horseradish peroxidase complexed with a positively charged polymer) was added. Cross-linking was obtained with glutaraldehyde. The reaction tube was spun at $12,000 \times g$ for $5 \mathrm{~s}$ to settle the reaction mixture in the bottom of the tube and incubated for 10 $\min$ at $37^{\circ} \mathrm{C}$.
Hybridisation with probe

The membrane filters were soaked in prehybridisation solution (Amersham International, UK) containing $0.5 \mathrm{M} \mathrm{NaCl}$ for 30 $\min$ at $42^{\circ} \mathrm{C}$. After prehybridisation, the labelled DNA probe was added to the hybridisation solution and the contents were mixed. The blots were then incubated with agitation at $42^{\circ} \mathrm{C}$ overnight. Washing of the blots was carried out as instructed by the manufacturer. For the computation of DNA fragment sizes, lambda DNA cleaved by HindIII (Boehringer Mannheim, Germany) was used as a $\mathrm{MWt}$ standard.

\section{Detection of the non-radioactive label}

Two detection reagents provided by the manufacturer were mixed in equal volumes before use. Detection reagent 1 contained hydrogen peroxide, the substrate for peroxidase. Detection reagent 2 contained luminol which produces blue light upon oxidation. For two membranes, $25 \mathrm{ml}$ of each reagent were mixed, poured on the membranes, and incubated at room temperature for one minute. The excess detection buffer was drained off and the blots were wrapped in Saran Wrap avoiding air bubble formation. The blots were placed DNA-side up in a film cassette with a sheet of autoradiography film (Hyperfilm MP, Amersham) and exposed for one min, after which it was replaced with a second sheet of film. The time of exposure of the second film was estimated from the appearance of the first film after it was developed. Generally, $20 \mathrm{~min}$ exposure time was used.

\section{Results}

$r R N A$ gene restriction patterns of gonococci Experiments with digestion of total genomic

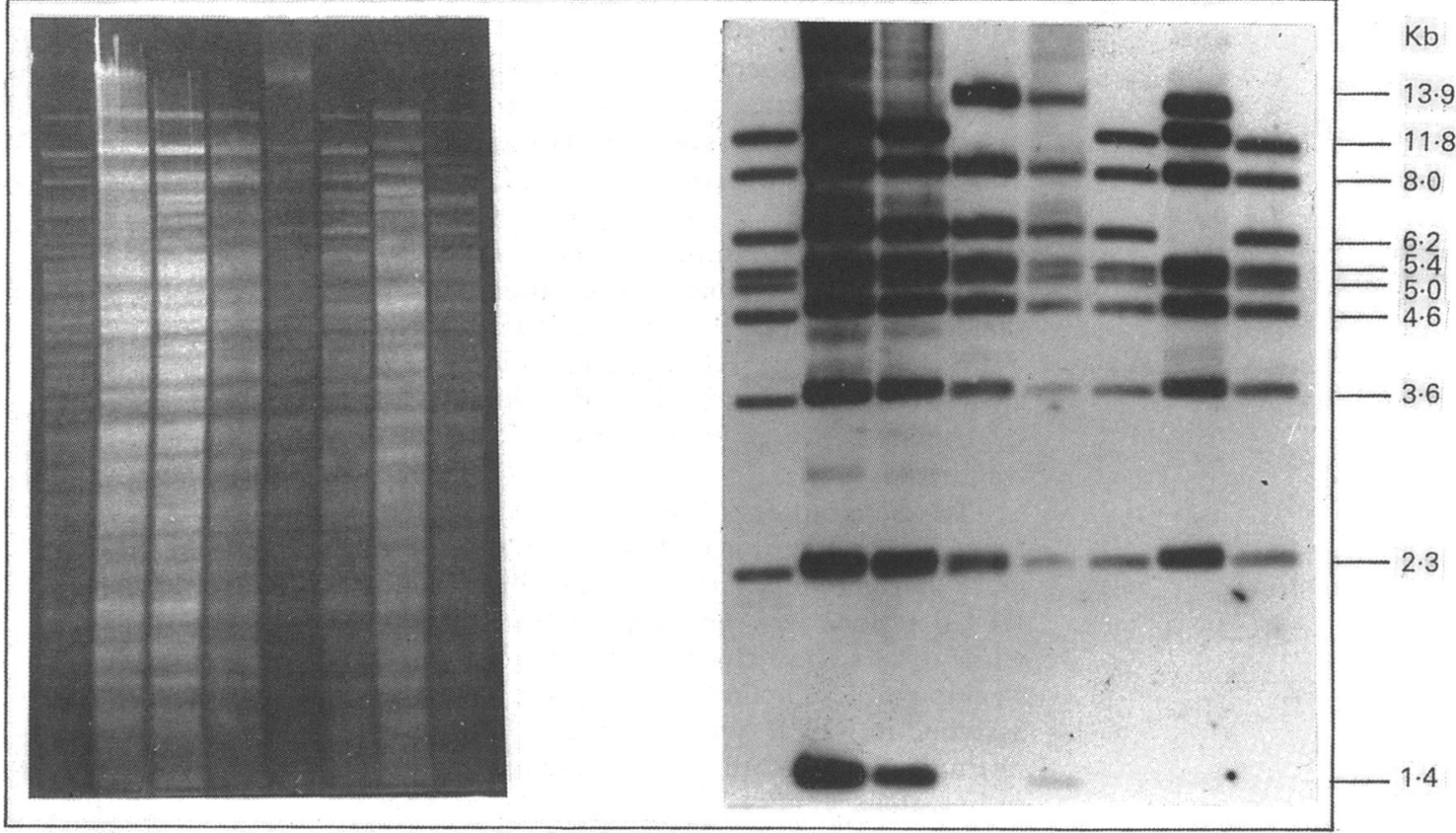

Fig 1 Restriction endonuclease patterns of total genomic DNA $(A)$ and ribosomal $R N A$ gene restriction patterns ( $B$ ) of $N$. gonorrhoeae strains digested with HincII. Lane 1, strain A11; lane 2, strain A14; lane 3, strain A15; lane 4, strain A16; lane 5, strain A17; lane 6, strain A18; lane 7, strain A19; lane 8, strain A20. 


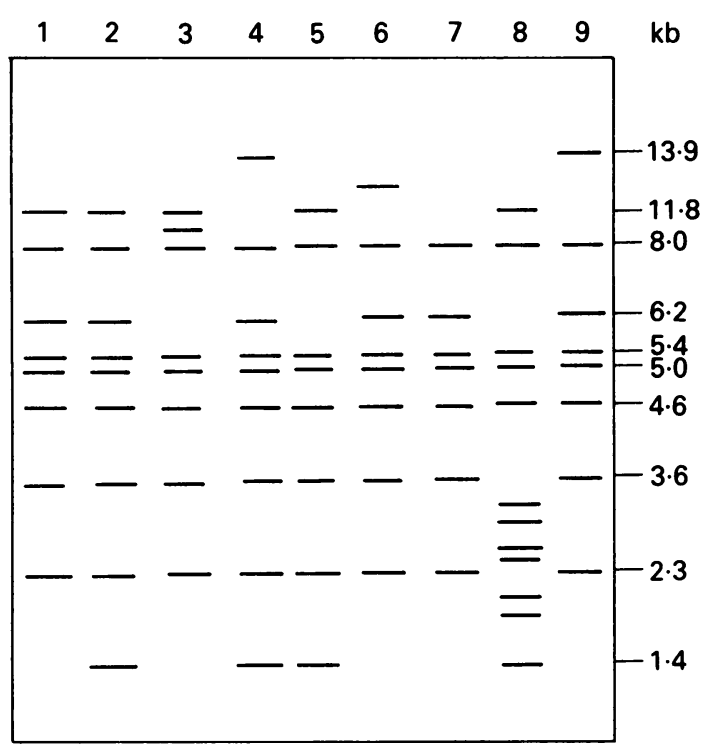

Fig 2 Schematic representation of RFLPs of $43 \mathrm{~N}$. gonorrhoeae strains obtained after digestion of total DNA with HincII and hybridisation with rRNA gene probe from $P$. aeruginosa.

DNA employing a variety of restriction endonucleases showed that HincII restriction produced rRNA gene restriction patterns that were most disriminatory as judged by the number and distribution of band positions after hybridisation with $P$ aeruginosa $16+23$ S rRNA genes (fig 1). Enzymes such as $E c o$ RI and CfoI which generated one or two hybridising bands were not chosen as no heterogeneity was observed in the hybridisation patterns of various strains examined.

Digestion of genomic DNA by HincII was found to produce between 8 to 12 hybridising fragments ranging in size from 1.4 to $13.9 \mathrm{~kb}$. Nine RFLP patterns comprising different molecular sized DNA fragments were revealed by HincII digestion of the 43 isolates (fig 2). The nine patterns possessed four common rRNA gene fragments which corresponded to sizes of approximately $4 \cdot 6,5 \cdot 0,5 \cdot 4$ and $8.0 \mathrm{~kb}$, respectively. RFLP type 1 (isolates A11, A18 and A20, fig 1) differed from RFLP type 2 (isolates A14 and A15, fig 1) by the presence of a single rRNA-containing fragment of $1.4 \mathrm{~kb}$. RFLP types 3 and 8 had hybridisation patterns that were significantly different from the rest. The remaining five RFLP patterns were quite closely related and each differed from the other by the presence of one to two rRNA gene fragments.

The distribution of gonococci into RFLP types was not uniform. Some of the patterns were shared by numerous strains, for example, RFLP type 2 was represented by 18 strains while others were characterised by one to two strains (table 1). Only one isolate each was assigned to EFLP types 3,6 and 8. This could be due to the small number of isolates examined rather than a very low prevalence of these patterns.

Reproducibility and stability of RFLP patterns The characteristic patterns of bands observed for each strain remained identical when DNA prepared from randomly selected strains grown on separate occasions during the course of the study were compared. Similarly, no differences in RFLP patterns were observed for strains subjected to serial subcultures.

\section{Comparison of RFLP with serological \\ characterisation}

Analysis of the hybridisation patterns of HincII digests showed that there were several strains belonging to the same serovar displaying the same RFLP pattern. For example, four strains of serogroup WI/serovar Aedih belonged to RFLP type 7 (table 2). However, strains belonging to the same serogroup/serovar could be further subdivided based on different RFLP patterns generated. Eleven strains of serogroup WI/serovar Aedih were subdivided into four RFLP types whilst two groups comprising six strains of WII: Back and five strains of WIII: Beghjk were each further resolved into three RFLP types. RFLP type 2 was the predominant group observed among the 9 HincII generated RFLP types. It was represented by 18 isolates which were distributed amongst different serogroups/serovars.

\section{Discussion}

Restriction site heterogeneity within rRNA genes has been found to generate RFLP patterns suitable for differentiation of genetically diverse groups of bacteria. The RFLP method is based on the detection of minor differences in a genetic locus such as that encoding rRNA genes. For this study, we have chosen a broad spectrum probe encoding rRNA genes cloned from $P$ aeruginosa. An earlier study by Stull $e t$ $a l^{11}$ showed that identical rRNA gene patterns could be produced by either a homologous or a

Table 1 Restriction fragment length polymorphism patterns of $\mathrm{N}$ gonorrhoeae strains

\begin{tabular}{|c|c|c|c|}
\hline RFLP type & Strain & RFLP type & Strain \\
\hline \multirow[t]{2}{*}{1} & $\begin{array}{l}\text { A1 } \\
\text { A10 } \\
\text { A11 } \\
\text { A18 } \\
\text { A20 } \\
\text { B3 } \\
\text { B6 } \\
\text { B8 } \\
\text { D14 }\end{array}$ & 3 & $\begin{array}{l}\text { A17 } \\
\text { D34 }\end{array}$ \\
\hline & D35 & 5 & $\begin{array}{l}\text { A19 } \\
\text { D37 } \\
\text { D47 }\end{array}$ \\
\hline \multirow[t]{5}{*}{2} & $\begin{array}{l}\text { A4 } \\
\text { A5 } \\
\text { A9 } \\
\text { A14 }\end{array}$ & 6 & $\begin{array}{l}31487 \\
\text { D25 }\end{array}$ \\
\hline & $\begin{array}{l}\text { A15 } \\
\text { B4 } \\
\text { B5 } \\
\text { B11 } \\
\text { B15 } \\
\text { D5 } \\
\text { D10 }\end{array}$ & 7 & $\begin{array}{l}\text { B2 } \\
\text { B7 } \\
\text { B9 } \\
\text { B14 } \\
\text { D18 }\end{array}$ \\
\hline & $\begin{array}{l}\text { D12 } \\
\text { D15 }\end{array}$ & 8 & 45469 \\
\hline & $\begin{array}{l}\text { D28 } \\
\text { D30 }\end{array}$ & 9 & $\begin{array}{l}\text { A16 } \\
69844\end{array}$ \\
\hline & $\begin{array}{l}\text { D32 } \\
\text { D42 }\end{array}$ & & \\
\hline
\end{tabular}


Table 2 Relationship between RFLP type and serological characteristics of the $43 \mathrm{~N}$ gonorrhoeae strains

\begin{tabular}{|c|c|c|c|c|c|}
\hline $\begin{array}{l}\text { Serogroup and } \\
\text { serovar }\end{array}$ & Strain & $\begin{array}{l}\text { RFLP } \\
\text { type }\end{array}$ & $\begin{array}{l}\text { Serogroup and } \\
\text { serovar }\end{array}$ & Strain & $\begin{array}{l}\text { RFLP } \\
\text { type }\end{array}$ \\
\hline WI:Aed & D28 & 2 & WII:Bajk & $\begin{array}{l}\text { A14 } \\
\text { D12 }\end{array}$ & 1 \\
\hline \multirow[t]{3}{*}{ WI:Aedih } & $\begin{array}{l}\text { A15 } \\
\text { A18 } \\
\text { B2 } \\
\text { B3 }\end{array}$ & $\begin{array}{l}2 \\
1 \\
7 \\
1\end{array}$ & & $\begin{array}{l}\text { D14 } \\
\text { D15 } \\
\text { D37 }\end{array}$ & $\begin{array}{l}1 \\
2 \\
5\end{array}$ \\
\hline & $\begin{array}{l}\text { B4 } \\
\text { B6 } \\
\text { B7 } \\
\text { B9 }\end{array}$ & $\begin{array}{l}2 \\
1 \\
7 \\
7\end{array}$ & WII: Bak & D18 & 7 \\
\hline & $\begin{array}{l}\text { B11 } \\
\text { B14 } \\
45469\end{array}$ & $\begin{array}{l}2 \\
7 \\
8\end{array}$ & WII:Bcegik & $\begin{array}{l}\text { A11 } \\
\text { D5 } \\
31487\end{array}$ & $\begin{array}{l}1 \\
2 \\
5\end{array}$ \\
\hline \multirow[t]{2}{*}{ WII: Bacejk } & $\begin{array}{l}\text { A5 } \\
42380\end{array}$ & $\begin{array}{l}2 \\
3\end{array}$ & WII:Bcgk & A16 & 9 \\
\hline & & & WII:Bcgjk & $\begin{array}{l}\text { A4 } \\
\text { D32 }\end{array}$ & $\begin{array}{l}2 \\
2\end{array}$ \\
\hline WII: Bacjk & $\begin{array}{l}\text { A19 } \\
\text { B15 } \\
\text { D25 } \\
\text { D42 } \\
\text { D47 }\end{array}$ & $\begin{array}{l}5 \\
2 \\
6 \\
2 \\
5\end{array}$ & WII:Bck & D30 & 2 \\
\hline WII: Back & $\begin{array}{l}\text { A10 } \\
\text { A17 } \\
\text { A20 } \\
\text { D21 } \\
\text { D34 } \\
\text { D35 }\end{array}$ & $\begin{array}{l}1 \\
4 \\
1 \\
2 \\
4 \\
1\end{array}$ & WIII: Beghjk & $\begin{array}{l}\text { A1 } \\
\text { A9 } \\
\text { B5 } \\
\text { D8 } \\
69844\end{array}$ & $\begin{array}{l}1 \\
2 \\
2 \\
1 \\
9\end{array}$ \\
\hline
\end{tabular}

heterologous probe. Many investigators have used a broad spectrum $16+23 \mathrm{~S}$ rRNA from $E$ coli that is available commercially. However, the need to make a cDNA copy employing reverse transcriptase would make the procedure unnecessarily complicated and costly. ${ }^{12}$ The $2 \cdot 2 \mathrm{~kb}$ BstEII fragment encoding the $16+23 \mathrm{~S}$ genes served as a good broad spectrum probe in this study as hybridising bands were seen with every strain. No strain was non-typable with this probe. RFLP patterns generated using this probe were also found to be both stable and reproducible.

The results of this study showed that RFLP typing based on rRNA gene heterogeneity was much simpler to interpret than the complex restriction fragment patterns of total genomic DNA digests. The rRNA gene patterns obtained using a non-radioactive probe in hybridisation reactions was found to be both sharp and highly discriminatory. A nonradioactive labelled probe was chosen as results from Koblavi et al ${ }^{13}$ demonstrated that the rRNA gene patterns obtained with the ECL gene detection system was as sensitive as ${ }^{32} \mathrm{P}$ autoradiography.

The choice of restriction endonucleases used was critical to the divergence of rRNA gene hybridisation patterns obtained. More pronounced heterogeneity of rRNA hybridisation patterns could be generated by restriction endonucleases that have different restriction sites within the rRNA cistrons. If a single copy rRNA gene is highly conserved and an enzyme used for restriction recognised a single site and generates only a single DNA fragment of identical molecular weight in all the strains examined, then this enzyme should not be selected. In our study, EcoRI was found not to have any restriction site in the DNA fragment encoding the rRNA genes and a single hybridising band was observed in all the strains examined. Both $\mathrm{ClaI}$ and HincII generated good restriction endonuclease (RE) digestion patterns of total genomic DNA. However, the HincII rRNA gene hybridisation patterns were found to be more useful for differentiation of strains as greater heterogeneity was observed in the number of hybridising bands in HincII rRNA gene restriction patterns than those generated by $C l a \mathrm{I}$.

The HincII rRNA gene restriction patterns observed were very much related as there were significant numbers of common DNA bands present in each ribotype. The highly conserved nature of rRNA genes was reflected by the presence of these common DNA bands. Nevertheless, heterogeneities in the rRNA genes existed and these were marked by the presence of unique DNA bands. These formed the basis of the present typing system. For example, RFLP types 1 and 2 were differentiated from each other in the presence or absence of a DNA band at $1.4 \mathrm{~Kb}$.

Based on RFLPs generated with HincII enzyme, we found no absolute correlation between rRNA gene restriction patterns and serotyping using monoclonal antibodies. Many strains with the same RFLP patterns were found distributed amongst several serovars (for example RFLP types 1,2 and 5). Strains with identical and different RFLP types were also found within each serovar. The present data demonstrate that both typing methods could be used advantageously to complement each other as isolates were subdivided by the alternative technique. RFLP typing is observed to offer an increased sensitivity over serotyping for differentiating serologically identical strains and non-typable strains. A combined typing system based on monoclonal antibody serotyping and RFLP subtyping will be very useful for differentiating $N$ gonorrhoeae strains in epidemiological studies. The option of using the RFLP technique on a non-radioactive basis makes this approach especially promising for use in non-reference labaratories and in developing countries.

We acknowledge the support of a National University Research Grant No RP 900369. We are grateful to Professor S M Bydgeman (Sweden) for the MAb serotyped $N$ gonorrhoeae Bydgeman (Sweden) for the MAb serotyped $N$ gonorrhoeae
strains and the kind gift of the pHF 1.1 probe from Professor K H Schleifer (Germany).

1 Sarafian SK, Knapp JS. Molecular epidemiology of gonorrhoea. Clin Microbiol Rev 1989;2(suppl):S49-55.

2 Bygdeman S. Polyclonal and monoclonal antibodies applied to the epidemiology of gonococcal infection. In: Young $H$, McMillan A, eds. Immunological Diagnosis of Sexually Transmitted Diseases. New York: Marcel Decker, 1987:117-65.

3 Gill MJ. Serotyping Neisseria gonorrhoeae: a report of the Fourth International Workshop. Genitourin Med 1991;67:53-7.

4 Falk ES, Bjorvatn B, Danielsson D, Kristiansen BE et al. Restriction endonuclease fingerprinting of chromosomal DNA of Neisseria gonorrhoeae. Acta Pathol Microbiol DNA of Neisseria gonorrhoeae. Acta
Immunol Scand Sect B 1984;92:271-8.

5 Poh CL, Ocampo JC, Sng EH, Bygdeman SM. Rapid in-situ generation of DNA restriction endonuclease patterns for Neisseria gonorrhoeae. J Clin Microbiol 1989;27:2784-8.

6 Saunders NA, Harrison TG, Haththotuwa A, et al. A method for typing strains of Legionella pneumophila serogroup 1 by analysis of restriction fragment length polymorphisms. J Med Microbiol 1990;31:45-55.

7 Bialkowska-Hobrzanska H, Harry V, Jaskot D, Hammerberg $O$. Typing of coagulase-negative staphylococci by Southern hybridization of chromosomal DNA fingerprints using a ribosomal RNA probe. Eur J Clin Microbiol 
1990;9:588-94.

8 Morgan DD, Owen RJ. Use of DNA restriction endonuclease digest and ribosomal RNA gene probe patterns to fingerprint Helicobacter pylori and Helicobacter mustelae isolated from human and animal hosts. Mol Cell Probes 1990;4:321-34.

9 Fox AJ, Jones DM, Gray SJ et al. An epidemiologically valuable typing method for Neisseria meningitidis by analysis of restriction fragment length polymorphisms. $J$ Med Microbiol 1991;34:265-70.

10 Schleifer KH, Ludwig W, Kraus J, Festl H. Cloned ribosomal ribonucleic acid genes from Pseudomonas aeruginosa as probes for conserved deoxyribonucleic acid sequences. Int $J$ Syst Bacteriol 1985;35:231-6.

11 Stull TL, LiPuma JJ, Edlind TD. A broad-spectrum probe for molecular epidemiology of bacteria: ribosomal RNA. $J$ Infect Dis 1988;158:280-6.

12 Garaizar J, Kaufmann ME, Pitt TL. Comparison of ribotyping with conventional methods for the type identification of Enterobacter cloacae. J Clin Microbiol 1991;29:1303-7.

13 Koblavi S, Grimont F, Grimont PAD. Clonal diversity of Vibrio cholerae 01 evidenced by rRNA gene restriction patterns. Res Microbiol 1990;141:645-57. 